\title{
The Effect of Push-Up Exercises on the Precision of Men's Permata Club Volleyball Smash
}

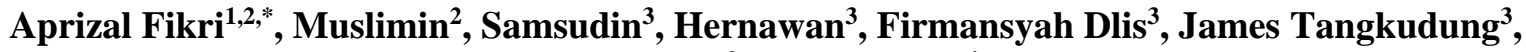 \\ Widiastuti $^{3}$, Arif Hidayat ${ }^{4}$
}

\begin{abstract}
${ }^{1}$ Sports Education Study Program (S3), State University of Jakarta, Moh Hatta Building, Rawamangun 13220, Jakarta, Indonesia ${ }^{2}$ Sport Education Study Program, Universitas Bina Darma, Jenderal Ahmad Yani No 3 Seberang Ulu I, 30111, Palembang, Indonesia ${ }^{3}$ Sport Science Faculty, State University of Jakarta, Rawamangun, 13220, Jakarta, Indonesia ${ }^{4}$ Faculty of Education and Teacher Training, Universitas Bina Darma, Palembang, 30264, Indonesia
\end{abstract}

Received May 11, 2021; Revised July 20, 2021; Accepted September 20, 2021

\section{Cite This Paper in the following Citation Styles}

(a): [1] Aprizal Fikri, Muslimin, Samsudin, Hernawan, Firmansyah Dlis, James Tangkudung, Widiastuti, Arif Hidayat, "The Effect of Push-Up Exercises on the Precision of Men's Permata Club Volleyball Smash," International Journal of Human Movement and Sports Sciences, Vol. 9, No. 6, pp. 1104 - 1108, 2021. DOI: 10.13189/saj.2021.090604.

(b): Aprizal Fikri, Muslimin, Samsudin, Hernawan, Firmansyah Dlis, James Tangkudung, Widiastuti, Arif Hidayat (2021). The Effect of Push-Up Exercises on the Precision of Men's Permata Club Volleyball Smash. International Journal of Human Movement and Sports Sciences, 9(6), 1104 - 1108. DOI: 10.13189/saj.2021.090604.

Copyright $\odot 2021$ by authors, all rights reserved. Authors agree that this article remains permanently open access under the terms of the Creative Commons Attribution License 4.0 International License

\begin{abstract}
The problem to be answered in this study is whether there is an effect of push-up training on smash accuracy in volleyball games at Club Permata. The purpose of this study was to determine the effect of push-up training on smash accuracy in volleyball at Club Permata. The research used in this research is pre-test and post-test which are experimental. Researchers collected data from 12 male players of Club Permata as the research sample. Data in this study are collected using test techniques. The type of test is a smash accuracy test. Based on the analysis with inferential statistical techniques, smash accuracy test obtained a calculation that is t_count of 16.55 with $t$ table with a significant level of $5 \%$ d.b: $(\mathrm{N}-1)(12-1)=11$ of 2.201 . So t_count is greater than table or $\mathrm{t} \_$count $=: 16.55>\mathrm{t} \_$table $=2.201$. The conclusion of this study is that push-up training can improve smash skills at Club Permata volleyball players. The contribution of this study is a new push-up training model that is appropriate for improving the accuracy of Club Permata's men's volleyball smash and can be implicated for other coaches in an effort to improve men's volleyball smash skills.
\end{abstract}

Keywords Exercise, Push Up, Accuracy, Smash

\section{Introduction}

Today, we have realized that the role of sport is becoming increasingly important. Almost all countries pay great attention to the development of sports in their countries, because sport does not only play a role in improving physical fitness and sports achievements of a nation but makes the nation proud. As in the development of sports in our country, it can be said that, little by little, progress is quite encouraging. This is proven by the existence of sports that have achieved national and international achievements, one of which is volleyball.

Volleyball is a team sport played by six people per team. This game will run well if at least every player has mastered the basic techniques of playing volleyball. The basic techniques of volleyball always develop in accordance with the development of knowledge, technology and other sciences. The basic techniques in volleyball include: (1) passing, (2) smash, (3) serving, (4) passing, (-5) dam. The game of volleyball starts with serving, with a service that uses good technique will be able to make the opponent lose control when receiving the service and will be an advantage (add points) for the opponent who serves, so serving is a basic technique that must be mastered well and right. In addition to mastering good basic volleyball techniques, there are elements that 
are no less important in playing volleyball. The element in question is the element of physical condition. Physical condition is a complete unity of several components that cannot be separated. Analyze the physical condition of the mechanics of the volleyball serve and smash [1]. Sports coaching can be done either through sports clubs at school or formal education. For junior high school students, they want new skills and develop a mind to learn fair play, good sportsmanship and want to use free time. One game that can be done in stages is a volleyball game. According to results of the research and expert's opinion, [2] "The volleyball game contains a series of individual technical-tactical actions that interact during the course of the game". According to [3]. Volleyball is a loving and exciting sport, but its poor promotion leads to a low number of consumers, especially in areas where this sport has no tradition. There are several types of basic techniques in volleyball games: service, passing, smash and block. The basic technique of volleyball according to the results of the study [4] states that "Volleyball is a complex sport where the results in the game depend on cooperation with each player who occupies a position in accordance with the rules of the game. Performance in volleyball games really requires a good psychomotor aspect and every player is trained. The ability to adapt in a team and physical and psychological abilities influence the outcome of the game ". According to [5]. "in a process of learning sports teams specifically in volleyball, basically using a tutorial that has a theoretical basis in a cognitive approach that covers the development of strength and skills. The physical condition referred to is strength, endurance, muscle strength, speed, flexibility, agility, balance, accuracy and reaction.

Arm muscle strength and abdominal muscle strength really help players when doing Smash, especially the accuracy in Smash. Smash is an attempt to enter the ball into the opponent's area by a back line player who is in the Smash area, to hit the ball with one hand or arm. The smash technique is very effective in generating points in a volleyball game [6]. A form of exercise to train arm strength is push-ups. This exercise can improve the ability of the arm muscles. The results showed that push-up training was appropriate for improving the basic technical skills of playing volleyball [7]. Observations on the accuracy of Smash in the volleyball game of Sigma Palu club on the ability to play volleyball have not been maximal. Especially doing a Smash in the course of a game mistakes often occur when smashing, for example the ball does not enter the opponent's area, the ball does not reach the net due to being blocked from the opposing player. This is a phenomenon that the strength of the arm muscles against the accuracy of the smash in the volleyball game of the gem club is not good so that the smash has not been fully mastered. The author intends to conduct research on the accuracy of smashes in volleyball games. The results of the research on the development of the smash training model were successful in improving volleyball smash skills [8].

Based on the problem and some result of the research, it is indicate that there is a need for the right solution to the imptovement of the smash skills of the jewels club volleyball players. Therefore, the researcher tries to provide a solution by making special exercises for arm strength so that it will improve the volleyball smash skills that are more accurate in the volleyball players of the Jewel Club men's volleyball. The results showed that arm strength and accuracy had an effect on the effectiveness of volleyball smash skills [9].

\section{Reseacrh Method}

The research method used is an experimental method with a pretest and posttest design as shown in the table.

Table 1. Pre-test and post-test experimental designs

\begin{tabular}{|c|c|c|c|}
\hline Subject & Pretest & Eksperiment & Posttest \\
\hline $\mathrm{R}$ & $\mathrm{O}_{1}$ & $\mathrm{P}$ & $\mathrm{O}_{2}$ \\
\hline
\end{tabular}

Keterangan :

$\mathrm{O}_{1}:$ (Prestest)

$\mathrm{P}$ : Experiment

$\mathrm{O}_{2}$ : Posttest

The steps taken in this research design are as follows.

a. Test the ability of Smash in the volleyball game before being given the treatment called the initial test $\left(\mathrm{O}_{1}\right)$

b. Treatment in the form of arm muscle strength training (P)

c. The test of Smash's ability in the volleyball game after being given a treatment is called the final test $\left(\mathrm{O}_{2}\right)$.

The population is the entire research subject (Arikunto, 2010: 173). The population that is the subject of this study is the entire Sigma Palu Volleyball Club, amounting to 12 people consisting of civil servants, students and private employees. The sample is part or representative of the population studied (Arikunto, 2010: 174). Sampling in this study used a total sampling technique (whole sample) because the number of 12 people was only taken from the population so the sample was 12 club sigma hammer players. Instruments are tools used to measure the variables under study.

The data collection technique in this research is a preliminary test, in the form of doing a smash before being given treatment in the form of arm muscle strength training and push-up exercises. After the treatment in the form of push-up exercises the final test is done, namely doing a smash after being given the push up training treatment. The field size is the same as the volleyball court size from PBVSI, namely $18 \mathrm{M}$ long, $9 \mathrm{M}$ wide and $2.43 \mathrm{M}$ net height for men. Then the size of the squares is 
made based on certain considerations, and the scoring weight is based on the difficulty level of directing the ball at a certain target. The size of the plots in the field can be described as follows.

The implementation of the Smash accuracy test. a. The test is in the smash area and performs valid Smash accuracy in accordance with the game rules that apply to smashes. b. Chance to smash 6 times in Scoring a. The score for each smash is determined by the ball over the net and the target number on which the ball falls. $b$. The ball that touches the target line is counted as having hit the target with the higher number. c. The ball that falls right on the square of the field will get a value according to the number in that tile. $d$. A ball that is played illegally or the ball touches the net and falls outside the court, the score is zero. e. The test was carried out 6 times. To its progress and improvement are seen in the seventh day of earch week. And the Smash accuracy value is the sum of the 4 best Smash scores. The steps for calculating data analysis are:

Table 2. The statistical calculations using the pre-test and post-test design patterns are as follows:

\begin{tabular}{|c|c|c|c|c|c|}
\hline No & XI & $\mathbf{X 2}$ & $\mathbf{D}(\mathbf{X 2 - X 1 )}$ & $\begin{array}{c}\text { d } \\
(\mathrm{D}-\mathrm{MD})\end{array}$ & $\mathbf{D 2}$ \\
\hline $\mathbf{1}$ & $\mathbf{2}$ & $\mathbf{3}$ & $\mathbf{4}$ & $\mathbf{5}$ & $\mathbf{6}$ \\
\hline & & & & & \\
\hline & $\sum \mathrm{XI}$ & $\sum \mathrm{X} 2$ & $\sum \mathrm{D}$ & $\sum \mathrm{d}$ & $\sum \mathbf{d}^{\mathbf{2}}$ \\
\hline
\end{tabular}

Information: XI: Score of pre-test / pre-test X2: Value of final / post-test $D$ : The difference of each pair d: the deviation of the difference d2: The square of the difference deviation $\sum$ : Total

After all the requirements mentioned above are met, statistical calculations using the t-test formula can be started. The t-test calculation in this study is based on the t-test analysis technique by Arikunto (2010: 349). The significance level can be seen at the 5\% similarity level.

\section{Reseacrh Result}

The following are the results of the study which can be seen in the following data analysis table.

Based on table 3, the total number of the initial test is $(\mathrm{X} 1=239)$ while the total number of final test results is $(\mathrm{X} 2=356)$. The different values from the initial test $(\mathrm{X} 1)$ and the final test (X2) are $\mathrm{d}=0$ and the variance value of the initial test and the final test is $(\mathrm{d} 2=46,28)$. The result of the mean deviation (MD) is 9,8. N The result of. The result of the calculation of the $t$-test is $(t=16,55)$.

From statistical calculations obtained $t$ count 16,55 by using a significant level of $5 \%$ of $\mathrm{db}=(\mathrm{N}-1)=12-1=11$, the value of $\mathrm{t}$ table is obtained: 2,201 , which means that the value of $t$ count is greater than $t$ table or 16,55>2,201. The results of data analysis using the t-test can be seen the level of significance of the effect of push up exercises on the results of the volleyball smash results.
Based on these results, the hypothesis states that there is an effect of push-up training on the accuracy of smash in volleyball games at Club Permata is accepted. Thus, there is a significant effect of push-up training on arm muscle strength on smash accuracy in the Club Permata volleyball game. The results of this study can be implemented for all athletes who want to improve the accuracy of volleyball smashes in various regions because research has been carried out and obtained significant results.

Table 3. Difference in accuracy of volleyball smashes before and after being given push-up exercises at Club Permata

\begin{tabular}{|c|c|c|c|c|c|}
\hline No & $\mathbf{X}_{\mathbf{1}}$ & $\mathbf{X}_{\mathbf{2}}$ & $\mathbf{X}_{\mathbf{2}}$ - $\mathbf{X}_{\mathbf{1}}$ & $(\mathbf{D}$ - MD) & $\mathbf{d}^{\mathbf{2}}$ \\
\hline 1 & 22 & 35 & 13 & 3,2 & 10,24 \\
\hline 2 & 18 & 29 & 11 & 1,2 & 1,44 \\
\hline 3 & 21 & 31 & 10 & 0,2 & 0,04 \\
\hline 4 & 20 & 29 & 9 & $-0,8$ & 0,64 \\
\hline 5 & 19 & 28 & 9 & $-0,8$ & 0,64 \\
\hline 6 & 22 & 30 & 8 & $-1,8$ & 3,24 \\
\hline 7 & 18 & 27 & 9 & $-0,8$ & 0,64 \\
\hline 8 & 17 & 30 & 13 & 3,2 & 10,24 \\
\hline 9 & 20 & 28 & 8 & $-1,8$ & 3,24 \\
\hline 10 & 21 & 32 & 11 & 1,2 & 1,44 \\
\hline 11 & 19 & 25 & 6 & $-3,8$ & 14,44 \\
\hline 12 & 22 & 32 & 10 & 0,2 & 0,04 \\
\hline $\mathbf{\Sigma}$ & 239 & 356 & 117 & 0 & 46,28 \\
\hline Mean & 19,92 & 29,66 & & & \\
\hline
\end{tabular}

\section{Discousion}

This study aims to determine whether there is an effect of push up training on the improvement of volleyball smash skills at the Permata club. The experimental research design was chosen to find out whether push up training could improve the results of Club Permata's volleyball smash skills. The experiment was carried out for 12 meetings by providing push-up exercises to 12 samples of the male sex. From the results of previous research, there are many training methods that can improve volleyball smash skills. Variations of basic volleyball technique exercises to improve the volleyball skills of junior high school students [10]. Relationship between general jump types and spike jump performance in elite female and male volleyball players [11]. The effect of arm muscle strength and leg muscle explosive power on volleyball smash ability [12]. The effect of smash practice without ball and still ball smash practice on volleyball smash ability [13]. From some of the results of these studies that the type of smash training can be done using various training models in accordance with the characteristics of the basic smash technique. 
Based on the results of data analysis, $t=16.55$ obtained $\mathrm{t}$ table $=2.201$, because $\mathrm{t}$ is greater than $\mathrm{t}$ table or 16.55> 2.201 at the $5 \%$ significance level, with a degree of difference $(\mathrm{db})=\mathrm{Nl}: 12-1=11$. The results of the data analysis are in line with the results of previous studies that examine the accuracy of volleyball games with the results of the research being that accuracy exercises can improve the accuracy of volleyball passing and smashes [14]. Based on these results, it can be concluded that push-up training has a significant effect on improving the smash skills of Club Permata's men's volleyball players. The result previous research on exercise improve vvolleyball smash skils[15]. Research result volleyball fundamental skills training [16]. The drill practice model improves volleyball smash skills [17]. Command training model in improving volleyball smash skills [18]. The target game training model improves the accuracy of volleyball smashes [19]. Hand eye coordination and motivation exercises improve the accuracy of volleyball playing skills [20]

The exercises given to experimental sample can improve volleyball smash skills and have a significant contribution from the results of data analysis to improving smash skills. After this research was carried out and contributed to the improvement of the volleyball smash results of Club Permata's men's volleyball, the results of this study can also be applied to other coaches who are conducting volleyball coaching, especially if the coach wants to improve smash skills, the results of this study can be used as a training model to improve volleyball game smash skills.

\section{Conclusion}

Based on the analysis and discussion of the results of the study, it can be concluded that push-up exercises can affect textual skills in volleyball, because the training material provided in the implementation of the research meets or is in accordance with the principles of training and training models. The volleyball training model contributes to the improvement of volleyball smash results [21]. The results of the study contributed significantly to improving the volleyball smash skills of Permata's boys.

\section{REFERENCES}

[1] J. C. Reeser, G. S. Fleisig, B. Bolt, and M. Ruan, "Upper Limb Biomechanics During the Volleyball Serve and Spike," Sports Health, 2010.

[2] Cojocaru, A., \& Cojocaru, M. (2018). Original Article Study on the efficiency of attack in the first division senior male in volleyball JPES ®, (5), 1976-1979. https://doi.org/10.7752/jpes.2018.s5292
[3] Luminița, a. E., \& valentina, ștefănică. (2017). Comparative study between marketing conducted in two volleyball clubs. Journal of Physical Education \& Sport, 17(5), 2274 2278.https://doi.org/10.7752/jpes.2017.s5243

[4] Florin, G., \& Bogdan C-Tin, R. (2013). Manifestation of the psychic adaptability skill in performance sport in female volleyball players of C.S. Stiința Bacau. Journal of Physical Education and Sport, 13(3), 381-385. https://doi.org/10.77 52/jpes.2013.03061

[5] Raiola, G. (2014). Teaching method in young female team of volleyball. Journal of Physical Education and Sport, 14(1), 74-78.https://doi.org/10.7752/jpes.2014.01012

[6] S. A. R. Putri, F. Dlis, Samsudin, M. Fajar, S. Wanto, and P. S. Sari, "The effect of smash training using hanging balls on the accuracy of open smash," Int. J. Hum. Mov. Sport. Sci., vol. 9, no. 1, pp. 135-139, 2021.

[7] F. N. Kurdi, Hartati, Y. Risnawati, and Destriana, "A variation of push up for overhead pass on volleyball games," Int. J. Hum. Mov. Sport. Sci., vol. 9, no. 1, pp. 97-102, 2021.

[8] I. A. Budiman, "Development model of volleyball spike training,” Int. J. Phys. Educ. Sport. Heal., 2016.

[9] D. Saptiani, S. Sugiyanto, and S. Syafrial, "HUBUNGAN KEKUATAN OTOT LENGAN DAN KOORDINASI MATA TANGAN TERHADAP AKURASI SERVIS ATAS BOLA VOLI PADA PESERTA PUTRI EKSTRAKURIKULER DI SMAN 2 SELUMA," KINESTETIK, 2019.

[10] S. A. Risma, F. Dlis, and S. Samsudin, "Variation of Volleyball Basic Technique Through Games Approach," Act. J. Phys. Educ. Sport. Heal. Recreat., 2020.

[11] P. X. Fuchs et al., "Relationship between general jump types and spike jump performance in elite female and male volleyball players," Appl. Sci., 2021.

[12] Wismiarti and Hermanzoni, "Pengaruh Kekuatan Otot Lengan Dan Daya Ledak Otot Tungkai Terhadap Kemampuan Smash Bolavoli,” J. Partriot, 2020.

[13] R. S. Massa and S. Kadir, "PENGARUH LATIHAN SMASH TANPA BOLA DAN LATIHAN SMASH BOLA DIAM TERHADAP KEMAMPUAN SMASH BOLAVOLI," Compet. J. Pendidik. Kepelatihan Olahraga, 2020.

[14] K. Aini, M. Asmawi, R. Pelana, J. Tangkudung, and Muslimin, "The effect of target and netting games on overhead pass volleyball accuracy," Int. J. Hum. Mov. Sport. Sci., vol. 9, no. 2, pp. 224-230, 2021, DOI: 10.13189/saj.2021.090209.

[15] M. Suhairi, M. Asmawi, J. Tangkudung, A. S. Hanif, and F. Dlis, "Development of SMASH skills training model on volleyball based on interactive multimedia," Int. J. Interact. Mob. Technol., 2020.

[16] D. J. Mcgeoch, Volleyball Fundamentals. 2018.

[17] Wahyu Cirana, Arif Rohman Hakim, and Untung Nugroho, "PENGARUH LATIHAN DRILL SMASH DAN UMPAN SMASH TERHADAP KETERAMPILAN SMASH BOLA VOLI PADA ATLET PUTRA USIA 13-15 TAHUN CdLUB BOLA VOLI VITA SOLO TAHUN 2020," J. Ilm. 
PENJAS (Penelitian, Pendidik. dan Pengajaran), 2021.

[18] I. S. Fallo and Hendri, "Upaya Meningkatkan Keterampilan Smash Permainan Bola Voli Melalui Pembelajaran Gaya Komando," J. Pendidik. Olahraga, 2016.

[19] Hermansyah and A. G. Permadi, "Peningkatan Ketepatan Smash Bola Voli Dengan Metode Target Games Pada Siswa Kelas XI SMA Darul Hikmah Tahunpelajaran 2017/2018," JISIP, J. Ilmu Sos. dan Pendidik., 2018.
[20] Subarna et al., "The effect of endurance, eye-hand coordination, and confidence to volleyball referee performance in West Java," Int. J. Hum. Mov. Sport. Sci., vol. 9, no. 3, pp. 436-444, 2021, DOI: 10.13189/saj.2021.090307.

[21] I. Muttaqin, M. E. Winarno, and A. Kurniawan, "Pengembangan Model Latihan Smash Bolavoli Pada Kegiatan Ekstrakurikuler di SMPN 12 Malang," Pendidik. Jasm., 2016. 